\title{
Seagrass surveys in the southern Rakhine coastal region, Myanmar: biodiversity, distribution and coverage
}

\begin{abstract}
Seagrass surveys were conducted at 9 study sites, in the southern Rakhine Coastal Region, to assess the species diversity, percent cover and extent of seagrasses for the better understanding of the current status and suitability of seagrass meadows for MPA designation. Among 9 study sites, except for Ma Gyi and Pho Htaung, the remaining 7 sites such as Tharthanar Dauk, Ngwe Saung, Wet Thay, Baw Di, Chan Pyin, Yay Myet Taung and Gyaing Kauk were newly recorded sites in the present surveys. There are two types of seagrass habitats: 1) intertidal habitats, mainly in shallow rock-pools at Baw Di and Yay Myet Taung; and 2) predominantly subtidal habitats at the remaining study sites. In the present surveys, a total of 10 species of seagrasses, namely Syringodiumisoetifolium, Cymodoceaserrulata, C. rotundata, Haloduleuninervis, H. pinifolia, Enhalusacoroides, Thalassiahemprichii, Halophilabeccarii, H. decipiensand H. major had been recorded. Among these, only one, Halophilabeccarii is was listed as Vulnerable on the IUCN RedList, while all other species were listed as Least Concern. Halophilabeccarii was only recorded at Pho Htaung. Halodulepinifolia was the most commonly observed species which was found in the remaining eight study sites. Pho Htaung, with the highest number of species (10 species) and coverage $(66.9 \%)$, and as the only site to contain the Vulnerable Halophilabeccarii, should be assigned to a Marine Protected Area (MPA), as well as along with Ma Gyi and Chan Pyin given their high species diversity and coverage.
\end{abstract}

Keywords: selective transfer, superficial layer, structural analysis, intensity x-rays, width of diffraction lines, crystalline network constant
Volume 7 Issue 2 - 2018

\author{
U Soe-Htun,' Antt Maung, ${ }^{2}$ Salai Mon, ${ }^{2}$ Tin \\ Zaw Tun, ${ }^{3}$ AungAung Hteik, ${ }^{4}$ Moe Lwin \\ Lwin, ${ }^{5}$ Zaw Tun, ${ }^{6} \cup$ Zau Lunn, ${ }^{7}$ Sue Murray- \\ Jones ${ }^{8}$ \\ 'U Soe-Htun, Director, Marine Science Association, Myanmar \\ ${ }^{2}$ Marine Biologist and Research Diver in Marine Conservation \\ Programme in Fauna \& Flora International (FFI), Myanmar \\ ${ }^{3}$ MSc Candidate, Department of Marine Science, Pathein \\ University, Myanmar \\ ${ }^{4}$ Assistant Lecturer, Department of Marine Science, Pathein \\ University, Myanmar \\ ${ }^{5}$ Assistant Lecturer, Department of Marine Science, Myeik \\ University, Myanmar \\ ${ }^{6}$ Fishery Officer, Gwa Township, Rakhine State, Myanmar \\ ${ }^{7}$ Director, Fauna \& Flora International (FFI), Myanmar \\ Marine Biologist, Lecturer, Flinder University of South Australia, \\ Australia
}

Correspondence: $\cup$ Soe-Htun, Director, Marine Science Association, Myanmar, (MSAM), Yangon, Myanmar Email:usoehtun@gmail.com

Received: February 21, 2018 | Published: April 10, 2018

\section{Introduction}

Seagrasses are a group of submerged flowering plants of approximately 72 species, representing a relatively small group, less than $0.1 \%$ of the angiosperm taxa growing in shallow coasts of the tropical and subtropical regions. ${ }^{1,2}$ Seagrasses provide a wide range of valuable ecosystem services, both direct and indirect. ${ }^{3}$ About $60 \%$ of seagrass meadows globally have been seen reductions in their distribution since 1980 due to habitat destruction and marine pollution. ${ }^{13}$ Rates of decline have accelerated from $0.9 \% \mathrm{yr}^{-1}$ before 1940 to $7 \% \mathrm{yr}^{-1}$ since $1990 .{ }^{4}$

Seagrasses occur all along three Coastal Regions of Myanmar (Rakhine, Ayeyarwady Delta and the Gulf of Mottama (Martaban), and Tanintharyi). Eleven species of seagrasses has been recorded in Myanmar, including Syringodiumisoetifolium(Ascherson) Danty, Cymodoceaserrulata(R. Brown) Aschersonet Magnus, C. rotundata Ehrenberg et Hemprich ex Ascherson, C. $s p$, Haloduleuninervis(Forsskal) Ascherson, H. pinifolia(Miki) den Hartog, Enhalusacoroides(Linnaeus f.) Royle, Thalassiahemprichii(Ehrenberg) Ascherson, Halophilabeccarii Ascherson, H. decipiens Ostenfeld and H. ovalis(R. Brown) Hooker f. and H.major(Zoll.) Miquel. ${ }^{510}$

Myanmar people call seagrasses as Leik-Sar-Phat-Myet in Myanmar, meaning the food of marine turtles. Myanmar seagrass meadows support five species of marine turtles, all of which are IUCNlisted threatened species; the olive ridley turtle (Lepoidochelyolivacea;
Vulnerable), loggerhead turtle (Carettacaretta; Vulnerable), green turtle (Cheloniamydas; Endangered), hawksbill turtle (Eretmochelysimbricata; Critically Endangered), and the leatherback turtle (Dermochelyscoriacea; Vulnerable). ${ }^{8,12}$ In addition, the seagrass meadows along the Rakhine Coastal Region are known to serve as important feeding grounds for the sea cow, Dugong dugon, which is listed as Vulnerable on the IUCN Red list. ${ }^{1012}$

This study was undertaken to provide updated information on the current status on biodiversity, distribution and coverage of seagrasses at selected sites along the southern Rakhine Coastal Region of Myanmar, comprising southernmost coastal areas of the Rakhine State, and west coastal areas of the Ayeyawady Region. This information will be used to inform the establishment of Marine Protected Areas (MPAs) within the southern Rakhine Coastal Region to ensure such habitats which should be conserved. The results of this study will provide a baseline for long term monitoring studies on seagrasses. This study was carried out under the project entitled "Capacity Building for Coastal Biodiversity Monitoring: Mawdin Coast Partnership, Myanmar, Phase I: (2016) of Fauna \& Flora International (FFI)",

\section{Materials and methods}

\section{Study sites}

The Rakhine Coastal Region is located in the western part of Myanmar, facing the Bay of Bengal, between the Naaf River of 
Myanmar- Bangladesh Border and the Mortin Point between the Cape Negrea is and mouths of the Ayeyawady River (Figure 1). The salinity ranges and temperature ranges of coastal waters of the Rakhine Coastal Region are $32-34 \%$ and $30-32^{\circ} \mathrm{C}$, respectively, during the study period of March and November 2016. Tides in all study sites regularly occur twice a day throughout a year. The tidal range is about $3 \mathrm{~m}$ in height along the Rakhine Coastal Region.
In the administrative point of view, the Rakhine Coastal Region was divided into 2 parts: 1) Ayeyawady Region in the southern part; and 2) Rakhine State in the northern part. Five study sites in Ayeyawady Region and four study sites in the south of Rakhine State were selected for surveys on seagrasses (Figure 1)(Table 1). Coordinates for each study site were recorded by GPS and given in Table 2.The following sites (with relevant acronyms) were surveyed:

Table I Diversity of seagrasses distributed in nine study sites in the Ayeyawady Region and Rakhine State in the southern Rakhine coastal region of Myanmar.

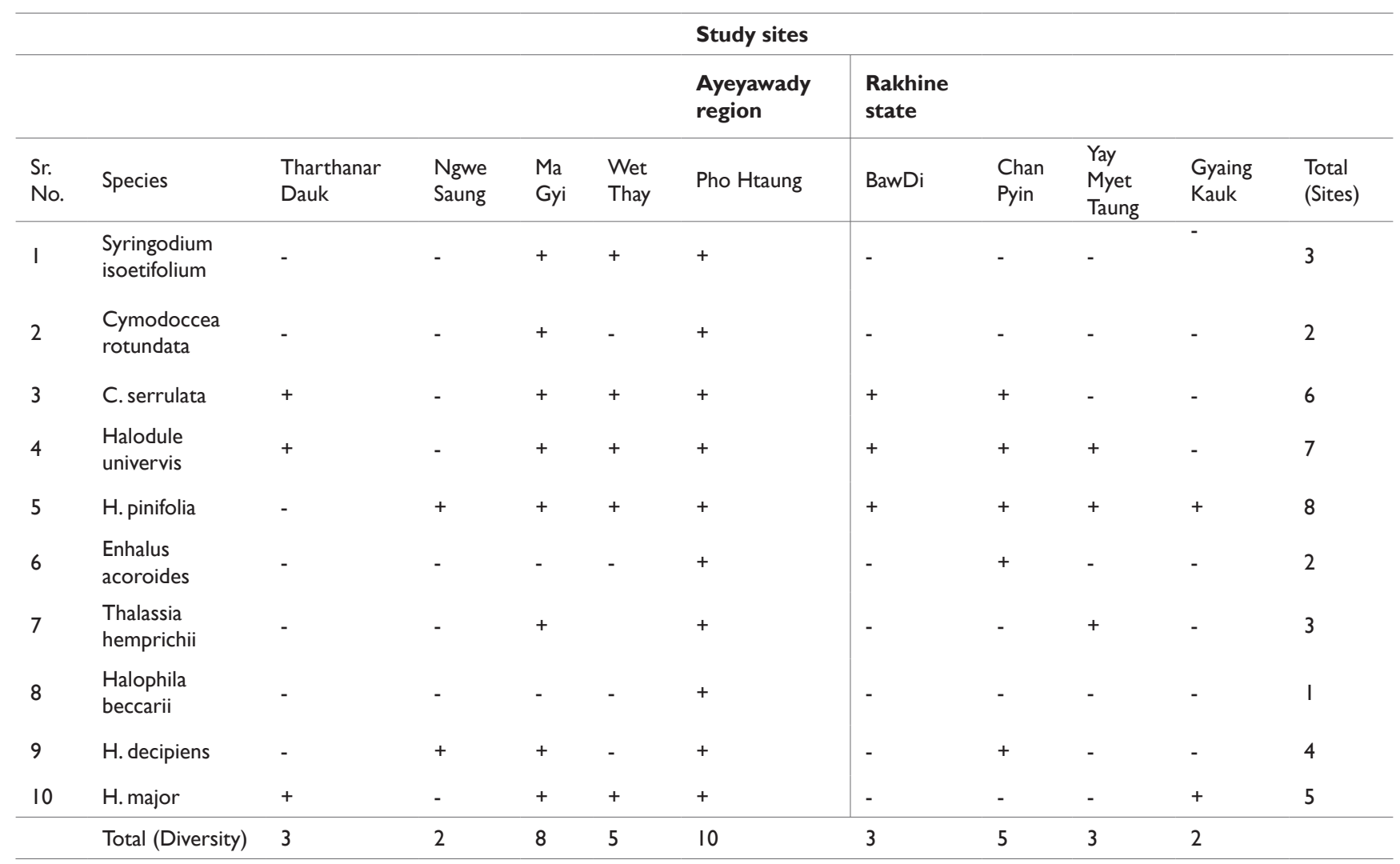

Symbols: + = Present; - = Absent. Total (Sites) = Occurrence.

Ayeyawady Region: All study sites are subtidal.

a. Tharthanar Dauk (TD): Located in the corner of northern MiChaungGaung, with sand-mud substrate.

b. Ngwe Saung (NS): Located in the corner of MwayKyun Island, with sandy substrate.

c. Ma Gyi (MG):Located in the corner of Ma Gyi tidal creek, with sand-mud substrates.

d. Wet Thay (WT): Located in the northern corner of Wet Thay, with sand-mud substrates.

e. Pho Htaung (PH): Located in front of mangroves, with mud-sand substrates.

f. Rakhine State: Twostudy sites are intertidal and another 2 study sites are subtidal.

g. Baw Di (BD): Located in front of a rocky shelf without mangroves. This site is Intertidal with sandy substrate in very shallow rockpools. h. Chan Pyin (CP): Located in front of mangrove communities in the northern part of Gwa Aw, with mud-sand substrates, subtidal.

i. Yay Myet Taung (YMT): Located in front of the rocky platform with mangrove communities. This site is Intertidal with sandy substrates in very shallow rock-pools.

j. Gyaing Kauk (GK): Located in front of a sandy beach without mangroves, with sandy substrates in the subtidal zone from nearshore to offshore.

\section{Taxonomic studies}

Fresh and live materials of seagrasses growing in the nine study sites were sampled by uprooting the seagrasses with a small trowel or knife in depths between $0-5 \mathrm{~m}$ in March and November 2016. The collections were washed, cleaned and preserved in $10 \%$ formalin in seawater. Samples of seagrasses were examined mainly on the vegetative characters under a dissecting microscope, and then pressed on herbarium sheets to prepare as voucher specimens for each locality. All specimens were identified using the standard 
monograph of seagrasses prepared by den Hartog ${ }^{13} \&$ Kuo et al..$^{14}$ This study followed the classification system used by Fortes. ${ }^{15}$ All voucher specimens were deposited at the Herbarium of the Department of Marine Science, Pathein University, Myanmar.

\section{Ecological studies}

This study has followed the SeagrassNet protocol by Short et al. ${ }^{16,17}$ consisting of three fixed, parallel, $50 \mathrm{~m}$ cross-transects referred to as cross-transects $\mathrm{A}, \mathrm{B}$ and $\mathrm{C}$, with cross-transect $\mathrm{A}$ closest to shore and $\mathrm{C}$ most seaward; $\mathrm{B}$, midpoint of these cross-transects were established laid out seaward, perpendicular to the shore. Percentage of seagrasses was visually estimated within 12 randomly place quadrats $\left(50 \mathrm{~cm} \times 50 \mathrm{~cm}, 0.25 \mathrm{~m}^{2}\right)$ along each cross-transect using a photo guide of percent cover. As noted above, these works were done intertidally in the coastal areas of Baw Di and Yay Myet Taung but subtidally in the remaining study sites, using snorkeling or scuba equipment.

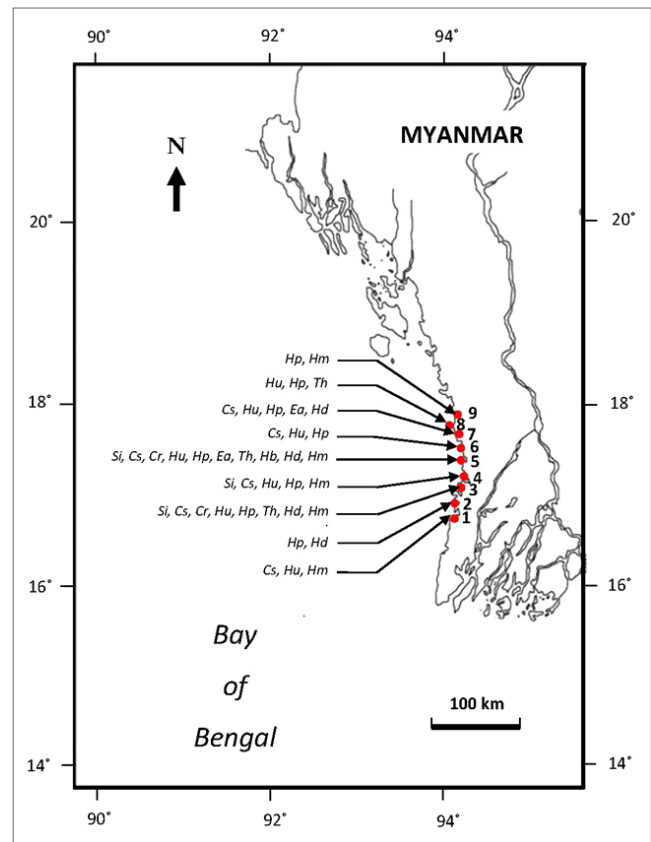

Figure I Map showing the biodiversity and distribution of seagrasses growing along 5 study sites in the Ayeyawaddy Region: I. Tharthanar Dauk; 2. Ngwe Saung; 3. Ma Gyi; 4.Wet Thay; 5. Pho Htaung; and 4 study sites in the southern Rakhine State: 6. Baw Di; 7. Chan Pyin; 8. Yay MyetTaung; 9. GyaingKauk. Abbreviations: Si, Syringodiumisoetifolium; Cr, Cymodocearotundata; Cs, C. serrulata; Hu, Haloduleuninervis; Hp, H. pinifolia; Ea, Enhalusacoroides; Th, Thalassiahemprichii; $H b$, Halophilabeccarii; Hd, H. decipiens;and Hm, H. major.

\section{Results}

A total of 10 species of seagrasses (Figures 2-11) collected from the southern Rakhine Coastal Region, were identified: Syringodiumisoetifolium(Ascherson) Danty; Cymodocearotundata Ehrenberg et Hemprich ex Ascherson; C. serrulata(R. Brown) Ascherson et Magnus; Haloduleuninervis(Forsskal) Ascherson; $H$. pinifolia(Miki) den Hartog; Enhalusacoroides(Linnaeus f.) Royle; Thalassiahemprichii(Ehrenberg) Ascherson; Halophilabeccarii Ascherson; H. decipiens Ostenfeld; and H. major (Zoll.)Miquel (Table 1). Determination wasbased on the following characters used as taxonomic key to the species of seagrasses collected from the southern Rakhine Coastal Region:

1a.Leaf blade cylindrical....

\section{Syringodiumisoetifolium}

1b. Leaf blade flat.

2a. Leaves strap-shaped.................3

2b. Leaves paddle-shaped...........8

3a. Leaves with ligula..................4

3b. Leaves without ligula.................. 7

4a. Leaf tip smoothly rounded.

\section{Cymodocearotundata}

4b. Leaf tip distinctly dentate or serrated. .5

5a. Leaf tip distinctly serrated C. serrulata

5b. Leaf tip bi- or tri-dentate .6

6a. Leaf tip tri-dentate, the black central leaf vein not split at the tip............Haloduleuninervis

6b. Leaf tip bi-dentate, the black central leaf vein split into two at the tip...........H. pinifolia

7a. Leaves 10-15 $\mathrm{mm}$ wide with ribs at the margin, leaf margins enrolled, rhizones with long black fibrous bristles Enhalusacoroides

7b. Leaves 4-10 mm wide without ribs at the margin, leaf margins not enrolled, rhizones with triangular leaf.......Thalassiahemprichii

8a. Leaves linear to lanceolate, 1 - $3 \mathrm{~mm}$ wide with 1-3 paralleled veins ....... Halophilabeccarii

8b. Leaves lanceolate to oblong, 3-10 mm wide with 6-20 crossveins....9

9a. Leaves blade small and lanceolate, margin serrate, with hairs on one or both sides of the blade.....H. decipiens

9b. Leaves blade large and ovate, margin entire, smooth without hairs on one or both sides of the blade......H. major

Distribution of seagrasses at the nine sites was very patchy, ranging between 0 and $100 \%$ cover at the quadrat level, and 3 and $69 \%$ at the transect level. BD had the lowestcover, with $12.1 \%( \pm 2.7$, S.E.) cover over the site, while PH had the highest cover, $66.9 \%$ ( \pm 6.3 , S.E.) (Figure12)(Table 2).

Some areas of seagrass were extensive, and coverage varied from high to very sparse or may be restricted to a few plants amongst rocks. At two sites(YMT and BD), seagrasses were confined to patches of sediment trapped on intertidal rocky platform, with no subtidal components. Seagrasses in the Rakhine coastal area range from intertidal meadows to solely subtidal areas, with the majority of sites extending into the subtidal. In the sites surveyed during the monsoon season (which ended around 6 weeks later than normal in 2016), many seagrasses were partially buried by muddy sand.

The most common species found in the study sites were Halodulepinifolia, which was found at eight sites, and H. uninevis, which was found at seven sites (Table 1). There was a mean number of $4.7( \pm 0.9$, S.E.) species per site, varying from two to ten species. No surveyed sites were monospecific. The two sites with the least diversity (only two species each) included both the most northerly site (GK) and the most southerly (NS). 
Table 2 Coverage of seagrasses in 9 study sites in the southern Rakhine Coastal Region of Myanmar.

\begin{tabular}{|c|c|c|c|c|c|c|c|}
\hline \multirow[t]{2}{*}{ Region/State } & \multirow[t]{2}{*}{ Sr.No. } & \multirow[t]{2}{*}{ Study site (Date) } & \multirow[t]{2}{*}{ Position } & \multicolumn{4}{|c|}{$\begin{array}{l}\text { Cover }(\%) / \text { Cross- } \\
\text { transect }\end{array}$} \\
\hline & & & & $A$ & B & C & Total \pm S.E \\
\hline & I & $\begin{array}{l}\text { Tharthanar Dauk } \\
(4-11-2016)\end{array}$ & Lat 16.60744 , Long 94.32393 & 52.9 & 32.3 & 23.8 & $36.3 \pm 3.0$ \\
\hline \multirow[t]{2}{*}{ Ayeyawady Region } & 2 & Ngwe Saung (14-3-2016) & Lat 16.89036, Long 94. 37624 & 35.5 & 48.6 & 53.6 & $45.9 \pm 2.9$ \\
\hline & 3 & Ma Gyi (I2-3-2016) & $\begin{array}{l}\text { Lat } 17.072122 \text {, Long } 94 . \\
451406\end{array}$ & 34.2 & 40.8 & 36.6 & $37.2 \pm 5.7$ \\
\hline \multirow[t]{2}{*}{$\begin{array}{l}\text { Rakhine Coastal } \\
\text { Region }\end{array}$} & 4 & Wet Thay (I2-II-20I6) & Lat I7.I4I55, Long 94.4652 I & 28.5 & 46.7 & 52.5 & $42.6 \pm 3.5$ \\
\hline & 5 & Pho Htaung (I2-3-2016) & $\begin{array}{l}\text { Lat I7. I70547, Long } 94 . \\
491739\end{array}$ & 69.2 & 64.6 & - & $66.9 \pm 6.3$ \\
\hline \multirow[t]{4}{*}{ Rakhine State } & 6 & Baw Di (I7-3-20|6) & Lat 17.48720, Long 94.55687 & 3.3 & 18.3 & 14.6 & $12.1 \pm 2.7$ \\
\hline & 7 & Chan Pyin (16-3-2016) & Lat 17.633333, Long 94.55 & 67.9 & 37.3 & 61.7 & $55.6 \pm 4.6$ \\
\hline & 8 & Yay Myet Taung (19-3-2016) & Lat 17. 7, Long 94. 53333 & 44.6 & 54.2 & 14.8 & $37.9 \pm 4.8$ \\
\hline & 9 & Gyaing Kauk (18-3-20|6) & Lat 17.78935 , Long 94.48626 & 28.8 & 49.2 & 34.7 & $37.4 \pm 3.2$ \\
\hline
\end{tabular}

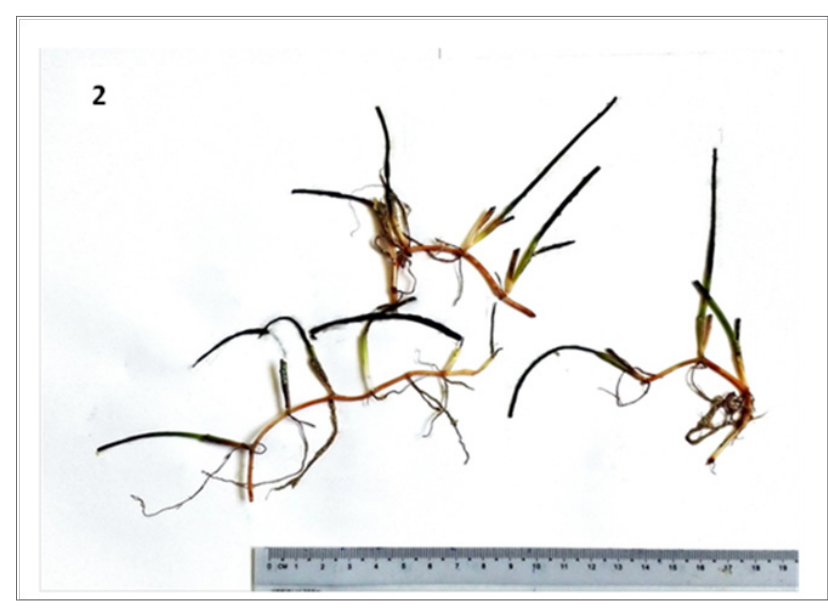

Figure 2 Habitats of Seagrasses. Syringodiumisoetifolium(Ascherson) Danty.

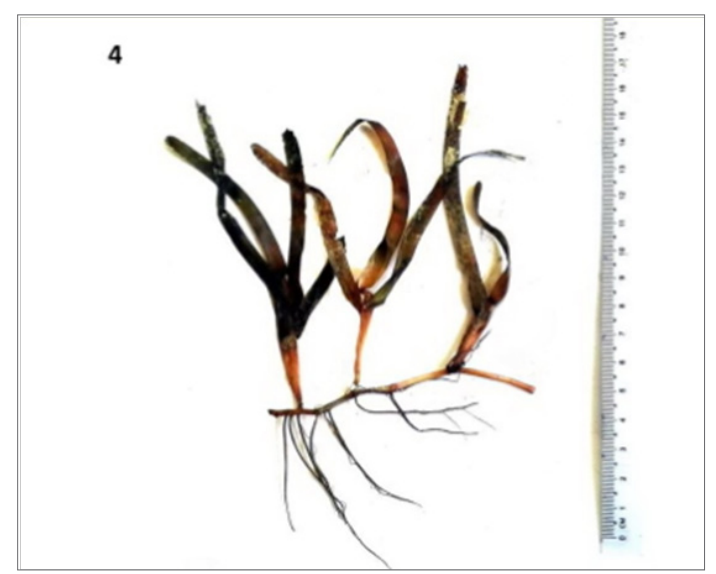

Figure 4 Habits of seagrasses.C. serrulata(R. Brown) Aschersonet Magnus.

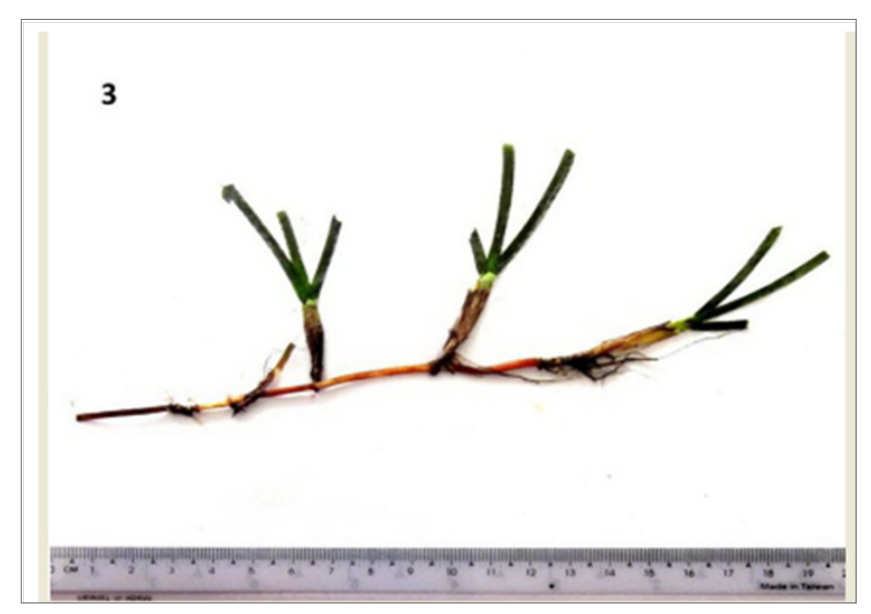

Figure 3 Cymodocearotundata Ehrenberg et Hemprich ex Ascherson.

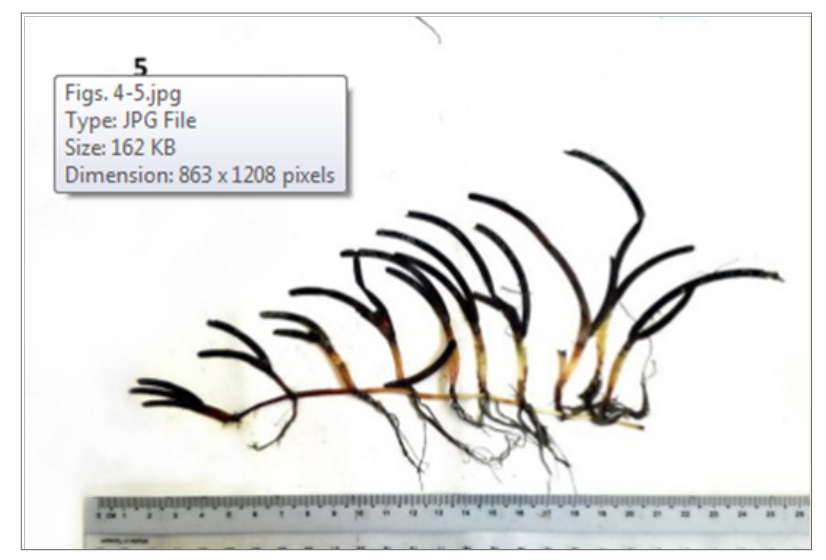

Figure 5 Haloduleuninervis(Forsskal) Ascherson.

Citation: Soe-Htun U, Maung A, Mon S, et al. Seagrass surveys in the southern Rakhine coastal region, Myanmar: biodiversity, distribution and coverage.J Aquac Mar Biol. 20 8;7(2): 103-I I0. DOI: 10.15406/jamb.2018.07.00I93 


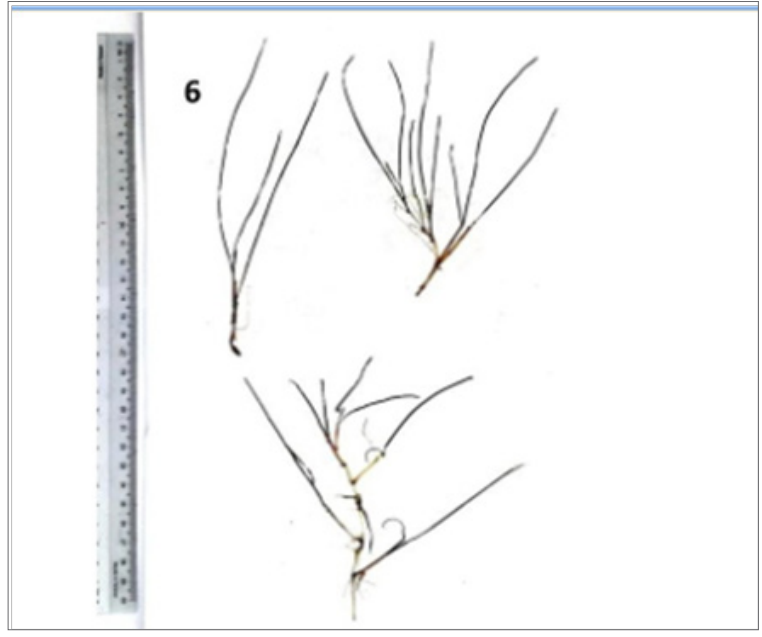

Figure 6 Habits of seagrasses. Halodulepinifolia(Miki) den Hartog.

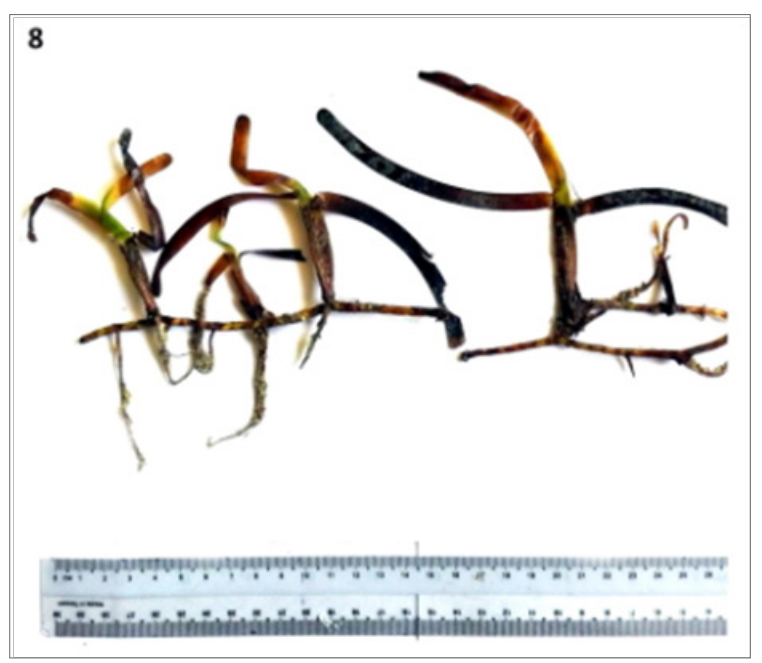

Figure 8 Habits of seagrasses. Thalassiahemprichii(Ehrenberg) Ascherson.

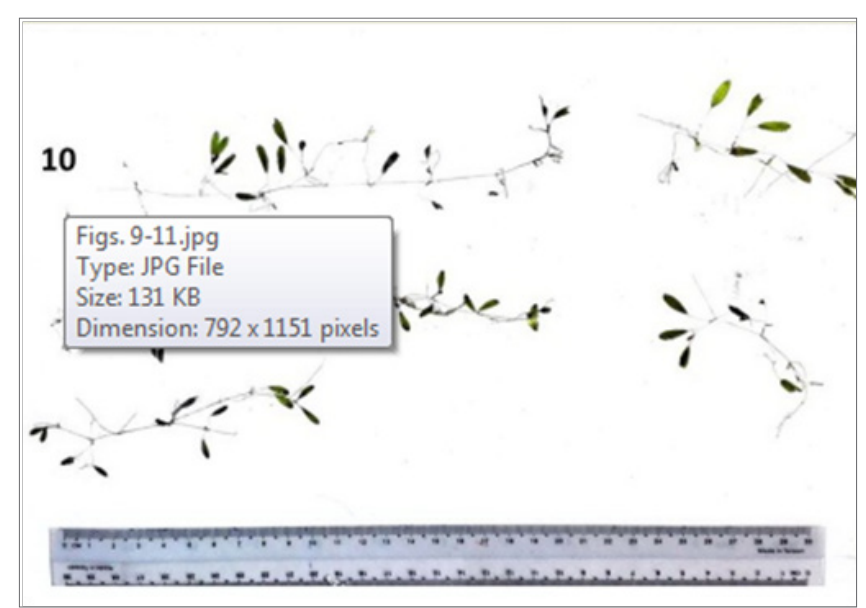

Figure 10 Habits of seagrasses. Halophiladecipiens Ostenfeld.

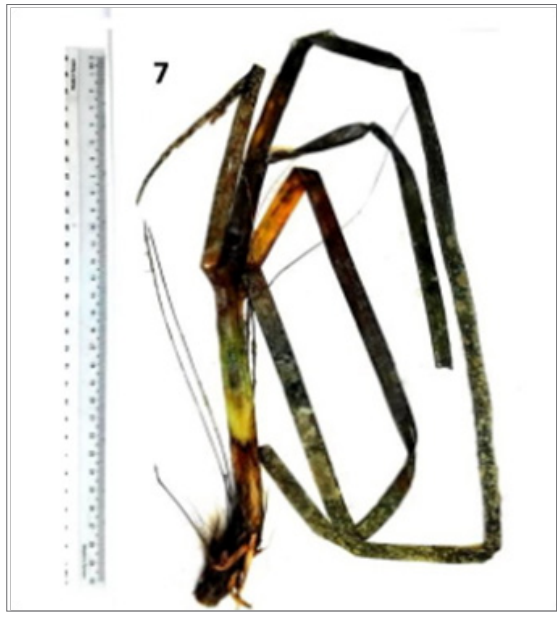

Figure 7 Enhalusacoroides(Linnaeus f.) Royle.

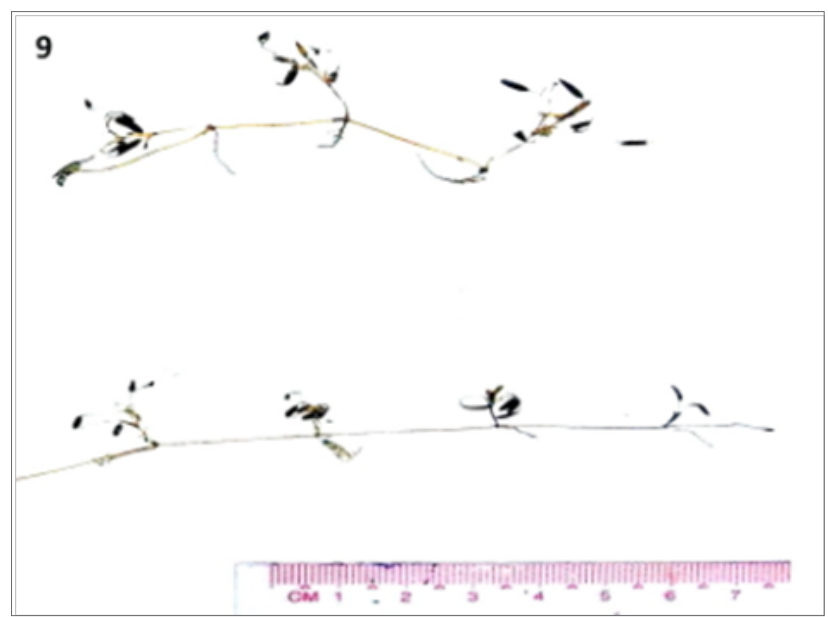

Figure 9 Halophilabeccarii Ascherson.

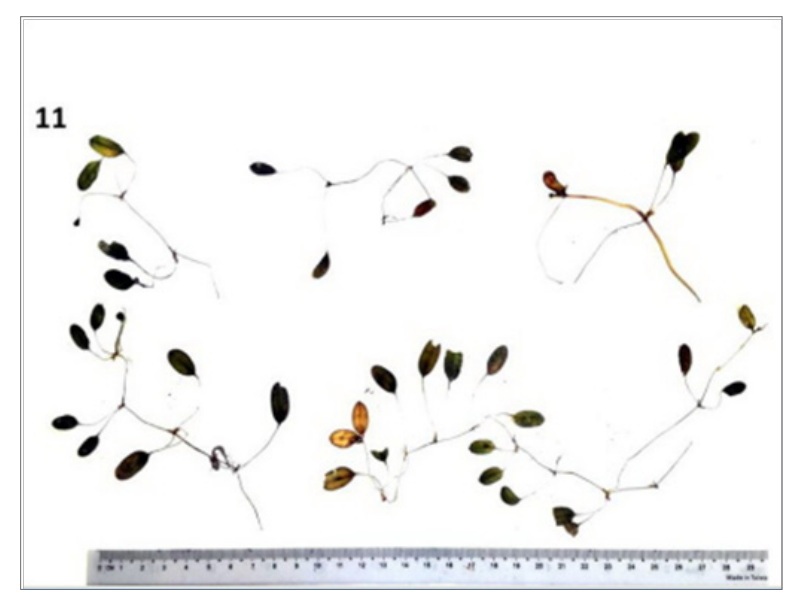

Figure II H. major (Zoll.) Miquel. 


\section{Discussion}

Ten species of seagrasses were found in the present study as of a previous study in $2015 . .^{10}$ Of these species, only Halophilabeccarii is considered as Vulnerable, along with all other species which are listed as Least Concern according to the IUCN RedList.

Figure 12 generally showed the coverage of most of the study site was estimated with means of 36 quadrats \pm standard error, where as that of one study site had missing data, notably $\mathrm{PH}$ where fading light meant one transect was not surveyed, hence $n=24$. PH showed a very high species composition and cover.Surveys were completed in March 2016 (solid bars) and November 2016 (hatched).

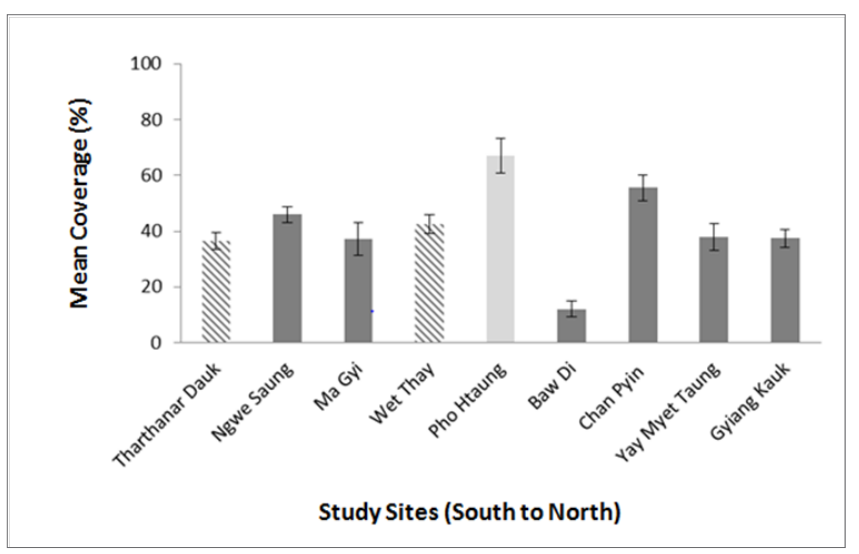

Figure 12 Mean coverage of seagrasses at nine sites in the southern Rakhine Coastal Region.
Of the 9 sites surveyed, only MG and PH had been previously studied using the same methodology, ${ }^{10}$ and so comparisons can be made. In such comparison, the percentage covers recorded in this study and in that of 2015 were similar: $39.3 \%$ and $37.2 \%$ in MG; $66.8 \%$ and $66.9 \%$ in $\mathrm{PH}$, respectively. The remaining 7 sites of TD, NS, WT, BD, CP, YMT, and GK were newly recorded sites in the present seagrass surveys.

The highest percentage cover of seagrass meadows was observed at $\mathrm{PH}$, in the Ayeyawady Region, with $66.9 \%$ and the highest coverage in Rakhine State at CP with $55.6 \%$, whereas the lowest was at BD with $12.1 \%$ (Figure 12)(Table 2). Luxuriant growth of seagrasses was observed in MG, WT and PH in the Ayeyawady Region and CP in the southern Rakhine State.

Two types of habitats of seagrasses were observed: 1) intertidal habitats of the rocky platforms- very shallow rock-pools at BD and YMT and 2) subtidal habitats at the remaining study sites. Seagrasses growing in YMT are associated with the agarophyte species, Gracilariaedulis (S.G.Gmelin) P.C.Silva which are daily collected by the coastal people for making salads.

Although Soe-Htun et al. ${ }^{7}$ reported there were no stresses in the meadows of seagrasses in coastal areas of Myanmar, with these ecosystems showing pristine, climax conditions, they are now facing problems such as smothering by sand of nearby runoffs during the monsoon season, extensive coastal development and clearing of mangroves, and other anthropogenic impacts such as bottom trawling and using beach seine nets on seagrass beds. Some bottom trawlers and fishers using beach seine nets also operate directly through seagrass beds targeting shrimps and other marine species, destroying these habitats.

Table 3 Seagrass sites ranked according to uniqueness, species richness and percentage cover with I being the highest priority for protection and 5 the least.

\begin{tabular}{|c|c|c|c|c|c|c|}
\hline $\begin{array}{l}\text { Sr. } \\
\text { No. }\end{array}$ & Site & Uniqueness & Species richness & $\%$ Cover & Cumulative score & Rank \\
\hline I. & TharthanarDauk & 5 & 7 & 2 & 14 & 4 \\
\hline 2. & NgweSaung & 4 & 7 & 2 & 13 & 4 \\
\hline 3. & Ma Gyi & 2 & 3 & 2 & 7 & 2 \\
\hline 4. & Wet Thay & 3 & 5 & 2 & 10 & 3 \\
\hline 5. & Pho Htaung & I & I & 1 & 3 & I \\
\hline 6. & Baw Di & 6 & 7 & 3 & 16 & 5 \\
\hline 7. & Chan Pyin & 2 & 6 & 1 & 9 & 3 \\
\hline 8. & Yay MyetTaung & 3 & 7 & 2 & 12 & 4 \\
\hline 9. & GyaingKauk & 5 & 7 & 2 & 14 & 4 \\
\hline
\end{tabular}

- Uniqueness: I = site has a species only found here; $2=$ site has species found here and at one other site, $3=$ site has species found here and at one other site etc.

- Species richness: $I=10$ species $; 2=9$ species; $3=8$ species; $4=7$ species; $5=6$ species $; 6=5$ species $; 7=<4$ species.

- \% Cover: $I=50-69 \% ; 2=30-49 ; 3=<29 \%$.

- Bolded indicate priority sites. 
Management actions are therefore required immediately to ensure these habitats are not lost which would have devastating consequences for both the aquatic environment and for people's livelihoods. Given the limited resources available in Myanmar to manage all these areas, focus must be steered towards those sites which could be considered key biodiversity areas. Therefore, to prioritize the most important sites and focus management interventions a simple ranking system was developed for the surveyed areas using uniqueness (in terms of species representation), species richness and percentage seagrass cover (Table 3). Although all sites should receive some level of protection, six sites stood out in terms of the above parameters with $\mathrm{PH}$ in the Ayeyawady Region being ranked the most important site being 1) one of the most diverse, 2) the only site to contain Halophilabeccarii, the most threatened of all the 10 species recorded with a ranking of Vulnerable under the IUCN Redlist, and 3) because of its high percentage cover Other sites worthy of immediate protection include MG and WT in Ayeyawady Region, and CP in Rakhine State. As a first step these sites should be provided some level of protection either as strict no-take MPAs or with carefully managed gear restricted areas with a strong emphasis on bottom trawlers and other gears which may negatively impact the seagrass.

The current study will allow the development of a baseline data for nine seagrass sites along the southern Rakhine Coastal Region, to allow for long-term monitoring of seagrass beds and provide the ability to quantitatively measure the impact of development as well as management interventions aimed at seagrass conservation.

\section{Conclusion}

This study provides the updated information on the current status on the biodiversity, distribution and coverage of seagrasses growing in nine selected sites along the southern Rakhine Coastal Region of Myanmar. The present seagrass surveys record 7 new study sites, namely Tharthanar Dauk, NgweSaung, Wet Thay, Baw Di, Chan Pyin, Yay Myet Taung and Gyaing Kauk, in addition to the previously recorded 2 study sites, Ma Gyi and Pho Htaung. In the present surveys, there are two types of seagrass habitats- intertidal and subtidal habitats. Baw Di and Yay Myet Taungre present as the type of intertidal habitats while the remaining sites show all subtidal habitats of seagrass beds. Of the 10 species collected, only Halophilabeccarii is considered as Vulnerable, while all the others are listed as Least Concern according to the IUCN RedList. Halophilabeccarii is recorded only at Pho Htaung whereas Halodulepinifolia is commonly predominant in 8 study sites except for one site of Tharthanar Dauk. It is necessary to do researches on the distribution of seagrasses growing along the southernmost coastal areas from the Mortin Point to the Ngayoke Aw of the Rakhine Coastal Region. Results here serve as information for the management of seagrass ecosystem in the southern Rakhine Coastal Region. Pho Htaung shows the highest species diversity (10 species) and percentage cover $(66.9 \%)$ in the Ayeyawady Region, while Chan Pyin represents as highest species diversity (5 species) and percentage cover $(55.6 \%)$ in Rakhine State. For that reason, Pho Htaung, being the only site to contain the Vulnerable listed Halophilabeccarii species and because of its high percent cover, should be assigned to a Marine Protected Area (MPA) along with Ma Gyi, Wet Thay and Chan Pyin which revealed their high species richness and coverage of seagrasses.

\section{Acknowledgements}

The first author, U. Soe-Htun is very grateful to the late Dr. U. Min-Thein, Director (Retd), Microalga Biotechnology Department, Myanmar Phamaceutical Factory (MPF), Yangon, Myanmar for invaluable guidance in the studies of seagrasses since his surveys in Maung Shwe Lay Gyaing in 1980. We would like to express our sincere thanks to Prof. (Retd) Dr. Htay Aung, Liaison Officer for the project, Dr Cherry Aung, Professor and Head, Department of Marine Science, Pathein University and staffs of Department of Marine Science, Pathein University for their helpful assistance during our field trips and office works. We are indebted to Robert Howard, FFI Myanmar's Marine Conservation Programme Manager, for his useful assistance during this study. Many thanks go to U Aung Myo Lwin, U Kyaw Kyaw Mon, U Zaw Lin Tun and U Nyo Min Thway, the staffs of the Marine Science Association, Myanmar (MSAM) for their assistance in the preparation of the manuscript. Supports for this work from Fauna \& Flora International (FFI) who manages the Ayeyawady Coastal Biodiversity Partnership are most appreciated.

\section{Conflicts of interests}

Author declares that there is no conflict of interest.

\section{References}

1. Green EP, Short FT. World atlas of seagrasses. UIMEP World Conservation Monitoring Centre, Berkeley, USA, University of California Press, 2003; $332 \mathrm{p}$.

2. Short FT, Carruthers T, Dennison W, et al. Global seagrass distribution and diversity: A bioregional model. Journal of Experimental Marine Biology and Ecology. 2007;350:3-20.

3. Orth RJ, Carruthers T, Denisson JB, et al. A global crisis for seagrass ecosystems. BioScience. 2006;56(12):987-996.

4. Waycott M, Duarte CM, Carruthers TJB, et al. Accelerating loss of seagrasses across the globe threatens coastal ecosystems. PNAS. 2009;106(30):12377-12381.

5. Min-Thein U, Aung-Myint U, Kyi-Shwe U. A list of some noteworthy species of marine algae and angiosperms from the Andrew Bay, Burma. Proceedings of the Burma Research Congress. 1979; p.10-17.

6. Soe-Htun U, San-Tha-Htun U, Aye-Mon-Sein, et al. A summary reports on the seaweeds and seagrasses of the Myeik (Mergui) Archipelago. Tech. Rep. 1997; 7 p.

7. Soe Htun U, San Tha Htun U, Mu Mu Aye. Notes on seagrasses along Myanmar Coastal Regions. Bull. Mar. Sci. Fish., Kochi Univ. 2001;20:1322 .

8. Soe-Htun U, Mya Kyawt Wai, ThidaNyunt, et al. Seagrass of Myanmar with special reference to the phytogeographic distribution of the species of ASEAN nations. Journal of Myanmar Academy of Art and Science. 2009; 7(5):263-387.

9. Tun T, Barry B. Preliminary observation on the seagrasses of Lampi and neighbouring islands of the Myeik Archipelago, Myanmar. Proceedings of the 6th International Symposium on SEASTAR 2000 and Asian Biologging Science (The 10th SEASTAR workshop), Thailand. 2011; p.8591.

10. Soe-Htun U, Antt Maung, Salai Mon, et al. Biodiversity, distribution and coverage of seagrasses in the Myeik Archipelago and Rakhine coastal areas, in Myanmar. J.Aquac. Mar. Biol. 2017;6(4):00164. 
11. Tun T, Ilangakoon AD. Capacity building and preliminary assessment on dugong (Dugong dugon) occurrence off the Rakhine Coast of Myanmar. Report to the Society for Marine Mammalogy. 2006.

12. International Union for Conservation of Nature (IUCN). The IUCN Red List of Threatened. Species. 2017.

13. Den Hartog C. The sea-grasses of the world. Amsterdam: North-Holland Publishing Company; 1970. 275 p.

14. Kuo J, den Hartog C. Seagrass taxonomy and identification key. In: Short FT, Coles RG editors. Global Seagrass Research Methods. Elsevier Science B. 2001;5:89-115.
15. Fortes MD. Seagrasses: Their role in marine ranching. In: Ohno M, Critchley AT, editors. Seaweed cultivation and marine ranching. Kanagawa International Fisheries Training Center Japan. International Cooperation Agency (JICA).1993. p. 131-151.

16. Short FT, Coles RG. Global seagrass research methods. Amsterdam. Elsevier Science. 2001; 506 p.

17. Short FT, Mc Kenzie LJ, Coles RG, et al. Seagrass Net manual for scientific monitoring of seagrass habitat. Worldwide Edition. University of New Hampshire Publication. 2006. 75 p. 